\title{
Physical Exercise and Its Protective Effects on Diabetic Cardiomyopathy: What Is the Evidence?
}

\begin{abstract}
Jia Zheng ${ }^{1,2 \dagger}$, Jing Cheng ${ }^{3 \dagger}$, Sheng Zheng ${ }^{4}$, Ling Zhang ${ }^{2}$, Xiaohui Guo ${ }^{2}$, Junqing Zhang ${ }^{2 *}$ and Xinhua Xiao ${ }^{1 *}$

${ }^{1}$ Key Laboratory of Endocrinology, Department of Endocrinology, Ministry of Health, Peking Union Medical College Hospital, Chinese Academy of Medical Sciences \& Peking Union Medical College, Beijing, China, ${ }^{2}$ Department of Endocrinology, Peking University First Hospital, Beijing, China, ${ }^{3}$ The Key Laboratory of Cardiovascular Remodeling and Function Research, Chinese Ministry of Education and Chinese Ministry of Health \& The State and Shandong Province Joint Key Laboratory of Translational Cardiovascular Medicine, Shandong University Qilu Hospital, Shandong, China, ${ }^{4}$ Department of Orthopedics, XiangYang Hospital of Traditional Chinese Medicine, Hubei, China
\end{abstract}

\section{OPEN ACCESS}

Edited by:

Zilin Sun,

Southeast University, China

Reviewed by:

Andrea Enzo Scaramuzza,

Istituti Ospitalieri di Cremona, Italy

Fang Zou,

Second Affiliated Hospital of

Nanchang University, China

*Correspondence:

Xinhua Xiao

xiaoxh2014@vip.163.com

Junqing Zhang

junqing.zhang@pkufh.com

tThese authors have contributed equally to this work

Specialty section: This article was submitted to

Diabetes,

a section of the journal

Frontiers in Endocrinology

Received: 28 September 2018 Accepted: 16 November 2018 Published: 03 December 2018

Citation:

Zheng J, Cheng J, Zheng S, Zhang L, Guo X, Zhang J and Xiao X (2018)

Physical Exercise and Its Protective

Effects on Diabetic Cardiomyopathy:

What Is the Evidence?

Front. Endocrinol. 9:729.

doi: 10.3389/fendo.2018.00729
As one of the most serious complications of diabetes, diabetic cardiomyopathy (DCM) imposes a huge burden on individuals and society, and represents a major public health problem. It has long been recognized that physical exercise has important health benefits for patients with type 2 diabetes, and regular physical exercise can delay or prevent the complications of diabetes. Current studies show that physical exercise has been regarded as an importantly non-pharmacological treatment for diabetes and DCM, with high efficacy and low adverse events. It can inhibit the pathological processes of myocardial apoptosis, myocardial fibrosis, and myocardial microvascular diseases through improving myocardial metabolism, enhancing the regulation of $\mathrm{Ca}^{2+}$, and protecting the function of mitochondria. Eventually, it can alleviate the occurrence and development of diabetic complications. Describing the mechanisms of physical exercise on DCM may provide a new theory for alleviating, or even reversing the development of DCM, and prevent it from developing to heart failure.

Keywords: exercise, diabetic cardiomyopathy, myocardial metabolism, oxidative stress, myocardial fibrosis, apoptosis

\section{INTRODUCTION}

The prevalence of type 2 diabetes mellitus (T2DM) continues to increase dramatically, and is now considered as an epidemic worldwide. It is estimated that the number of people with diabetes will exhibit a $45 \%$ increase in three decades (1). Uncontrolled diabetes can lead to a number of long-term health complications, including heart diseases, nerve damage, vision problems, and amputation. Among the various complications of diabetes, cardiovascular disease (CVD) represents the major cause of mortality and morbidity in diabetic patients, accounting for nearly $70 \%$ of related heart failure cases (2). Diabetic patients, when compared with nondisease subjects, are two to four times more likely to experience CVD events, due to micro- and macrovascular atherosclerosis, which is often exacerbated by the presence of concomitant CVD risk factors, including hypertension, dyslipidemia, and activation of neuro-hormonal and inflammatory mechanisms $(3,4)$. 


\section{THE PATHOGENESIS OF DCM}

Diabetic cardiomyopathy (DCM), a distinct condition that develops in diabetic patients, is defined by the presence of myocardial dysfunction in the absence of coronary atherosclerosis, overt clinical coronary artery disease (CAD), and valvular heart disease $(5,6)$. It is characterized by cardiac structure and function disorders, including myocardial fibrosis, dysfunctional remodeling, and associated metabolic deregulation and left ventricular dysfunction (7-9). DCM is associated with diastolic dysfunction, with depressed myocardial contractility and relaxation, and eventually by clinical heart failure (10). Left ventricular diastolic dysfunction with increased wall stiffness is common in subjects with well-controlled T2DM who are free of clinically detectable heart diseases (11). The pathogenesis of DCM is a multifactorial process that includes altered myocardial metabolism (impaired energy metabolism, calcium regulation, and mitochondrial function) $(12,13)$, increased oxidative stress (14), altered myocardial structure with fibrosis (15), higher induction of apoptosis (16), and microvascular disease (9).

\section{CURRENT STRATEGIES FOR DCM INTERVENTION}

Despite prominent advances in the prevention and treatment of diabetes, diabetic complications, especially for DCM still remain rigorous in patients with $\mathrm{T} 2 \mathrm{DM}(17,18)$. Nowadays, treatments for DCM include glucose and lipid control, hypertension treatment, and CAD intervention. Currently, pharmacological treatment is accepted as the common strategy for CVD in diabetic patients, such as $\beta$-blockers, $\mathrm{Ca}^{2+}$ antagonist, $\beta$-blockers, renin-angiotensin-aldosterone system inhibitors (9). In recent years, it demonstrated that metformin and sodium-dependent glucose transporters 2 (SGLT2) inhibitors are also benefit for DCM (19). A systematic review of observational studies showed that metformin reduced all-cause mortality in patients with diabetes with congestive heart failure (20). Pan et al. found that empagliflozin ameliorated DCM in diabetic ALDH2*2 mutant patients (21). However, the incidence and mortality rate of DCM still remains high. Physical exercise has been shown to improve health and quality of life in patients with a variety of diseases, including obesity (22), T2DM (23), chronic kidney disease (24), and cancers (25). Currently, physical exercise has been regarded as an importantly non-pharmacological treatment for the prevention and treatment of diabetes and its complications. It has been long known that physical activity can decrease the occurrence of cardiac events, including heart attacks and strokes, and the need for a coronary revascularization intervention (26-28). Exercise induces adaptations to the heart itself, as well as the cardiovascular system. These adaptations include protection against ischemic damage, increase of cardiac growth, and modulation of cardiac metabolism, function, and vascular supply (26). Myocardial apoptosis, myocardial fibrosis, and hemodynamic disorders caused by high glucose can be improved or even reversed by physical exercise. Studies have shown that exercise can improve myocardial metabolism, lower blood glucose, increase insulin sensitivity, inhibit myocardial fibrosis, improve oxidative stress, and decrease the risks of CVDs. Ultimately, it can improve heart function and decrease the mortality of DCM $(29,30)$.

\section{CLINICAL STUDIES ABOUT EXERCISE AND DIABETES-RELATED CARDIOVASCULAR DISEASES}

Physical activity plays an essential role in the maintenance of human health. Chronic diseases, such as metabolic syndrome and diabetes, are a tremendous burden to our society. Regular physical activity is a primary recommendation for the prevention and treatment of these diseases (36). Physical exercise has a wide array of beneficial effects, including improving glucose and insulin metabolism, and reducing the risks of CVDs in diabetic patients (37). The intensive weight loss intervention was effective in increasing physical activity and improving cardiorespiratory fitness in overweight and obese individuals with T2DM (31). Physical activity was associated with reduced risks of CVD,

TABLE 1 | Clinical studies about exercise and diabetes-related cardiovascular diseases.

\begin{tabular}{|c|c|c|c|}
\hline Subjects included & Exercise profile & Metabolic effects & References \\
\hline $\begin{array}{l}\text { 4,376 overweight or obese } \\
\text { adults with T2DM }\end{array}$ & $\begin{array}{l}\text { At least } 50 \mathrm{~min} / \text { week, progressing to } \\
\text { at least } 175 \mathrm{~min} / \text { week }\end{array}$ & $\begin{array}{l}\text { Increased physical activity } \\
\text { Improved cardiorespiratory fitness }\end{array}$ & Jakicic et al. (31) \\
\hline 575 patients with T2DM & $\begin{array}{l}\text { Low }(<4 \text { METs), moderate ( } \geq 4 \text { to }<7 \\
\text { METs) and high fitness ( } \geq 7 \text { METs) }\end{array}$ & $\begin{array}{l}\text { Lower hemoglobin A1c and C-reactive } \\
\text { protein levels } \\
\text { A decreased prevalence of left ventricular } \\
\text { hypertrophy and increased aortic stiffness }\end{array}$ & Cardoso et al. (33) \\
\hline 3,708 patients with T2DM & $\begin{array}{l}\text { Occupational, commuting, and } \\
\text { leisure-time physical activity }\end{array}$ & $\begin{array}{l}\text { Decreased total and cardiovascular } \\
\text { mortality }\end{array}$ & Hu et al. (34) \\
\hline 539 patients with T2DM & Leisure-time physical activity & Reduced risks of short-term CVD outcome & Karjalainen et al. (35) \\
\hline
\end{tabular}

CVD, cardiovascular disease; METs, metabolic equivalents. 
cardiovascular death, and total mortality in patients with T2DM $(32,38)$. In addition, the benefits of exercise may depend on the intensity of exercise. It showed that a moderate to high level of physical fitness was independently associated with several cardiovascular risk markers, which may contribute to decreasing the burden of morbidity and mortality in patients with T2DM (33). Hu et al. also showed that a moderate or high level of physical activity was associated with a reduced risk of total and cardiovascular mortality among patients with T2DM, which was regardless of the levels of body mass index, blood pressure, total cholesterol, and smoking (34). Furthermore, the duration of exercise is also an important factor for its benefits of CVD. Karjalainen et al. found that there was an inverse association between leisure-time physical activity and short-term CVD outcome. However, controlled, home-based exercise training had minor effects on the risk profile of CVD in CAD patients with T2DM. These findings highlight the significance of lifelong physical activity instead of a short-term exercise program in the prevention of future unfavorable outcomes in patients with CAD (35). However, clinical studies about exercise and its benefits in diabetes-related CVDs are limited. It is suggested to carry out long-term exercise program to ensure maximum exercise efficiency, with an appropriate amount of exercise. According to the evidence of the aforementioned studies and the 2018 guideline of American Diabetes Association (ADA) (39), we recommend a moderate to high level $[\geq 4$ to $<7$ metabolic equivalents (METs)] of physical fitness for patients with T2DM, such as $150 \mathrm{~min}$ or more of moderate-to-vigorous intensity aerobic activity per week. The clinical studies about exercise and diabetes-related cardiovascular diseases are listed in Table $\mathbf{1}$.

\section{PRE-CLINICAL EXPERIMENTS ABOUT PHYSICAL EXERCISE AND DCM}

\section{Physical Exercise Improves Cardiomyocyte Metabolism \\ Physical Exercise Increases Energy Metabolism}

Disorders of myocardial glucose and lipid metabolism lead to changes in pathways related with myocardial energy metabolism. Abnormalities that produce cardiac structure and function are called "metabolic remodeling of the heart," which ultimately leads to the development of cardiomyopathy. Glucose transporter-4 (GLUT-4) is an intracellular protein that can be translocated to cell membrane induced by insulin, and then it can participate in glucose uptake and utilization. The expression of GLUT-4 was decreased and abnormally distributed in diabetic state, resulting in a significant decrease in glucose transport and impaired myocardium energy utilization (58). Studies indicate that moderate exercise can upregulate GLUT-4 expression, and also can increase glucose transport and activate pyruvate dehydrogenase complexes, even in the absence of insulin (59). It suggests that exercise can compensate for impaired energy metabolism in insulin-deficient state, which may be related to the increase of insulin-sensitive adenosine monophosphate activated protein kinase (AMPK) expression, thereby protecting pancreatic $\beta$ cells. Exercise may also enhance insulin-mediated glucose transport by increasing the expression of protein kinase $C-\delta(60$,
61). Exercise can also increase insulin and its downstream protein expressions in the myocardium of diet-induced obesity rats, as well as forkhead box protein o1 (Foxo1) and other key regulators of pancreatic $\beta$ cells, and also activate insulin signaling pathway (40). Thus, exercise can protect pancreatic $\beta$ cells, promote insulin secretion, activate insulin signaling pathway, increase GLUT4 expression, improve intracellular energy metabolism, and ultimately protect cardiomyocytes.

\section{Physical Exercise Enhances Calcium Regulation}

Calcium is a crucial mediator of cell signaling in skeletal muscles for cellular functions and specific functions, including contraction, fiber-type differentiation, and energy production. Intracellular $\mathrm{Ca}^{2+}$ dyshomeostasis is one of the main markers of DCM, which can affect myocardial contractile function, directly leading to the occurrence and development of DCM. It is even worse in altered sarcoplasmic reticulum $\mathrm{Ca}^{2+}$ uptake rate accompanied by decreased function of sarcoplasmic reticulum $\mathrm{Ca} 2+-A T P a s e$ (SERCA2a) (62). In T2DM patients, the $\mathrm{Na}^{+}-\mathrm{Ca}^{2+}$ exchange of cardiomyocytes is inhibited, while the sarcoplasmic reticulum $\mathrm{Ca}^{2+}$ pump is normal, and $\mathrm{Ca}^{2+}$ is gradually concentrated in the sarcoplasmic reticulum. Thus, the amplitude and attenuation rate of $\mathrm{Ca}^{2+}$ concentration in the myocardium is decreased. Conversely, exercise can improve the expression and activity of SERCA2a, which can regulate $\mathrm{Ca}^{2+}$ release and recapture in the myocardium. Exercise can increase $\mathrm{Ca}^{2+}$-calmodulin-dependent protein kinase phosphorylation, reduce $\mathrm{Ca}^{2+}$ efflux, facilitate $\mathrm{Ca}^{2+}$ regulation, and ultimately improves myocardial contraction and diastolic function (41). Stølen et al. found that high intensity intermittent exercise improved myocardial contractility by restoring L-type $\mathrm{Ca}^{2+}$ channels, increasing the density of T-transverse tubules, and increasing the synchrony of $\mathrm{Ca}^{2+}$ release and excitatory contraction coupling (42).

\section{Physical Exercise Improves Mitochondrial Function}

Mitochondrion is the center of energy metabolism, and recent evidence suggests that mitochondrial dysfunction may play a critical role in the pathogenesis of DCM. The imbalance of energy supply and demand directly leads to the decline of myocardial function and induction of DCM (63). The ultrastructure of mitochondria in DCM shows reduced density, mitochondrial swelling, and destruction of the intima and adventitia, and an increase in mitochondrial matrix, while exercise attenuates diabetes-induced ultrastructural changes in rat cardiac tissue (43). Moderate exercise intervention has a protective effect on mitochondrial function. Exercise can regulate the key regulator of mitochondrial metabolism, peroxisome proliferator-activated receptor gamma co-stimulatory factor- $1 \alpha$ (PGC-1 $\alpha$ ), and activate its downstream transcription factors. Thus, it can enhance mitochondrial DNA replication and transcription, and increase mitochondria biosynthesis (44). Furthermore, the mechanisms by which exercise improves mitochondrial function may be related to the regulation of $\mathrm{Ca}^{2+}$ in mitochondria. $\mathrm{Ca}^{2+}$ is a key metabolic enzyme activator in mitochondria, and mitochondrial $\mathrm{Ca}^{2+}$ circulatory balance can be easily affected by intracellular $\mathrm{Ca}^{2+}$ homeostasis (41, 42). Resistance exercise improves cardiac function and 
mitochondrial efficiency in hearts, of diabetic rat, which were accompanied by higher expressions of mitochondrial biogenesis proteins such as PGC-1 $\alpha$ and mitochondrial transcription factor A (TFAM) (45). In addition, studies have shown that high intensity exercise can increase myocardial mitochondrial contents, but no change in moderate intensity exercise $(46,47)$. However, Veeranki et al. showed that moderate intensity exercise prevented DCM associated contractile dysfunction through restoration of mitochondrial function and connexin 43 levels in $\mathrm{db} / \mathrm{db}$ mice (30). These indicate that myocardial mitochondrial biosynthesis may be associated with exercise intensity, and exercise intensity should be further investigated about its effects on DCM.

\section{Physical Exercise Relieves Oxidative Stress Damage}

Oxidative stress is considered to be a key link in the development of DCM. Under physiological conditions, there is a balance system of oxygen free radicals and free radicals in the body. Oxygen atoms play an important role in the redox signaling pathway. Moderate oxidation can increase protein activity, but excessive reactive oxygen species can cause pathological changes through interaction with lipids, proteins, and DNA (64). Hyperglycemia can directly promote the production of oxygen free radicals, induce oxidative stress, and promote cardiomyocyte apoptosis. The mechanisms by which exercise ameliorates oxidative stress is complex, including: (1) reducing the production of reactive oxygen species. Exercise can ameliorate the damage caused by excessive oxidative stress in the diabetic myocardium and pancreas, thereby improving glucose metabolism and reducing damage caused by reactive oxygen species (48). Long-term exercise can also directly reduce the level of reactive oxygen species in the body by reducing the activity of nicotinamide adenine dinucleotide phosphate (NADPH) oxidase in diabetic rats (49). (2) Enhancing the ability of anti-oxidative stress. Exercise can increase the expression of nitric oxide synthase and nitric oxide, and ultimately enhance the antioxidant function in endothelial cells (49). Nuclear factor E2-related factor 2 ( Nrf2) can regulate the expressions of antioxidants mediated by antioxidant response elements. It is an important transcription factor for intracellular defense of reactive oxygen species $(50,65)$. Studies have shown that acute exercise can promote the function of Nrf2, activate downstream antioxidant response elements, and ultimately enhance the activity of anti-oxidative stress. In addition, knocking out the Nrf2 gene can increase the sensitivity of cardiomyocytes to oxidative stress, leading to increased oxidative damage in cells (50). Kanter et al. showed that low intensity exercise decreased the elevated tissue malondialdehyde (MDA) levels and increased the reduced activities of the enzymatic antioxidants superoxide dismutase (SOD), glutathione peroxidase (GSH-Px), and catalase (CAT) in cardiac tissue (51). It indicates that exercise improves the biological mechanisms of DCM by affecting the levels of plasminogen activator inhibitor 1 (PAI-1) and endothelial nitric oxide synthase (eNOS), and it is dependent on the intensity of exercise (52).

\section{Physical Exercise Improves Myocardial Fibrosis}

Myocardial fibrosis is the most prominent histopathological change in DCM, characterized by myocardial cell collagen deposition, interstitial fibrosis, and perivascular fibrosis, and ultimately induce the reconstruction of cardiac structure and function (53). Numerous studies indicated that moderate exercise can decrease blood glucose, reduce myocardial fibrosis, promote myocardial reverse remodeling in diabetic rats, and improve cardiac function $(30,53)$. The mechanisms may be that exercise reduces pressure overload by improving blood pressure, thereby alleviating myocardial fibrosis (53). Exercise can increase the content of matrix metalloproteinase-2 (Mmp2 ) in obese rats, increase the degradation of collagen and inhibit the formation of myocardial fibrosis (47). The interaction of collagen with glucose can further cause chemical modification of glycated collagen to form advanced glycation end products (AGEs) that promote arterial and cardiac cirrhosis, as well as endothelial dysfunction (66). Other mechanism by which exercise improves myocardial fibrosis may be related to improving energy metabolism, decreasing blood glucose, and myocardial glycogen deposition (54). Novoa et al. showed that high intensity chronic exercise had a positive impact on cardiac remodeling, evidenced as reduction in myocyte hypertrophy, reduced collagen deposition, and amelioration of myocardial fibrosis (55).

\section{Physical Exercise Inhibits Cardiomyocyte Apoptosis}

Diabetes-induced cardiomyocyte apoptosis is a typical feature of DCM. Hyperglycemia can directly promote cytochrome C release to the cytoplasm by activating cytochrome $\mathrm{C}$ in mitochondria, triggering cascade activation of caspase-3, leading to endogenous apoptosis of cardiomyocytes. This change plays an important role in the development of diabetic cardiac hypertrophy, myocardial remodeling, and heart failure. C-Jun N-terminal kinase is a member of the mitogen-activated protein kinase (MAPK) family, which can activate caspase- 8 and the apoptotic protein Bax, and release cytochromes to promote apoptosis (67). Veeranki et al. found that exercise can also reduce cytochrome $\mathrm{C}$ leakage into cytoplasm by increasing mitochondrial transmembrane potential, thus prevent cardiomyocyte apoptosis (30). A number of studies have shown that exercise can reduce the phosphorylation of c-Jun $\mathrm{N}$-terminal kinase in obese rats, block the transmission of downstream apoptotic signals. Exercise can also increase the expression of B-cell lymphokine 2 in the myocardium of diabetic mice, which can affect the activation of pro-apoptotic proteins by binding to proapoptotic proteins, and ultimately play an anti-apoptotic role on cardiomyocytes in diabetic mice (56). Kanter et al. showed that low intensity exercise had a therapeutic effect on diabetes-induced morphological, biochemical, and apoptotic changes in the cardiac tissue of rats (51). Khakdan et al. found that high intensity interval training effectively increased the expression of Sirtuin 1 (Sirt1) and B cell leukemia/lymphoma 2 
TABLE 2 | Pre-clinical experiments about physical exercise and DCM.

\begin{tabular}{|c|c|c|c|}
\hline Animals & Exercise intervention & Main findings & References \\
\hline \multicolumn{4}{|c|}{ PHYSICAL EXERCISE IMPROVES CARDIOMYOCYTE METABOLISM } \\
\hline Diet-induced obesity rats & $\begin{array}{l}\text { Treadmill running ( } 50-\mathrm{min} / \text { day, } 5 \text { days per week } \\
\text { velocity of } 1.0 \mathrm{~km} / \mathrm{h} \text { for } 2 \text { months) }\end{array}$ & $\begin{array}{l}\text { - Increased protein levels of phospho-P38MAPK, } \\
\text { REDD1 in the myocardium } \\
\text { - Decreased 14-3-3 protein levels in the } \\
\text { myocardium }\end{array}$ & Pieri et al. (40) \\
\hline STZ-induced diabetic SD rats & $\begin{array}{l}\text { accumulated about } 3,554 \mathrm{~m} / \text { day of voluntary } \\
\text { wheel running for } 12 \text { weeks }\end{array}$ & $\begin{array}{l}\text { - Prevented diastolic dysfunction in diabetic mice } \\
\text { - Normalized sarcoplasmic reticulum protein content } \\
\text { and expression in diabetic animals } \\
\text { - Enhanced SERCA2a activity }\end{array}$ & Epp et al. (41) \\
\hline $\begin{array}{l}\text { Cardiomyocytes from mice with } \\
\text { T2DM }(\mathrm{db} / \mathrm{db})\end{array}$ & $\begin{array}{l}13 \text { weeks of aerobic interval training ( } 4 \text { min at } \\
85-90 \% \text { of } \mathrm{VO}_{2 \max } \text { and } 2 \text { min at } 50 \% \text { of } \\
\mathrm{VO}_{2 \text { max }} \text { for } 80 \text { min /day, } 5 \text { days/week) }\end{array}$ & $\begin{array}{l}\text { - Restored contractile function associated with } \\
\text { restored } \mathrm{SR} \mathrm{Ca}^{2+} \text { release synchronicity, T-tubule } \\
\text { density, twitch } \mathrm{Ca}^{2+} \text { amplitude, SR } \mathrm{Ca}^{2+} \text { ATPase } \\
\text { and } \mathrm{Na}^{+} / \mathrm{Ca}^{2+} \text {-exchanger activities, and SR-Ca }{ }^{2+} \\
\text { leak } \\
\text { - Reduced phosphorylation of cytosolic CaMKIl } \delta \\
\text { - Normalized enhanced fractional } \mathrm{Ca}^{2+} \text { release }\end{array}$ & $\begin{array}{l}\text { Stølen et al. } \\
(42)\end{array}$ \\
\hline STZ-induced diabetic SD rats & $\begin{array}{l}\text { Run daily on a treadmill for } 9 \text { weeks (60 } \\
\mathrm{min} / \text { day, at a pace of } 20 \mathrm{~m} / \mathrm{min} \text { ) }\end{array}$ & $\begin{array}{l}\text { - Attenuated diabetes-induced changes in collagen } \\
\text { fibrils, cytoplasmic area, and level of mitochondrial } \\
\text { disruption }\end{array}$ & $\begin{array}{l}\text { Searls et al. } \\
(43)\end{array}$ \\
\hline C57BL/6 db/db mice & $\begin{array}{l}\text { Run daily on a treadmill for } 15 \text { weeks }(10 \mathrm{~m} / \mathrm{min} \\
\text { for } 1 \mathrm{~h} / \text { day) }\end{array}$ & $\begin{array}{l}\text { - Reversed reduction in EF and FS } \\
\text { - Reversed reduction of mtDNA replication and } \\
\text { transcription, together with reduced mtDNA content } \\
\text { and impaired mitochondrial ultrastructure } \\
\text { - Activated PGC-1 } 1 \alpha \text { and Akt signaling }\end{array}$ & $\begin{array}{l}\text { Wang et al. } \\
(44)\end{array}$ \\
\hline $\begin{array}{l}\text { Otsuka Long-Evans Tokushima } \\
\text { Fatty rats }\end{array}$ & $\begin{array}{l}20 \text { repetitions of climbing a ladder } 5 \text { days per } \\
\text { week for } 12 \text { weeks }\end{array}$ & $\begin{array}{l}\text { - Increased EF and FS } \\
\text { - Increased mitochondrial numbers } \\
\text { - Higher expression of PGC-1 } \alpha \text { and TFAM }\end{array}$ & Ko et al. (45) \\
\hline C57BL/6J mice & $\begin{array}{l}10 \text { weeks of treadmill running ( } 4 \text { min at } 85-90 \% \\
\text { of } \mathrm{VO}_{2 \max } \text { ) }\end{array}$ & $\begin{array}{l}10 \% \text { increase in heart weight-to-body weight ratio } \\
36 \% \text { increase in glucose oxidation and a } \\
\text { concomitant reduction in fatty acid oxidation }\end{array}$ & $\begin{array}{l}\text { Hafstad et al. } \\
(46)\end{array}$ \\
\hline $\begin{array}{l}\text { Diet-induced obesity C57BL/6 } \\
\text { mice }\end{array}$ & $\begin{array}{l}8-10 \text { weeks of treadmill running ( } 4 \text { min at } \\
\left.85-90 \% \text { of } \mathrm{VO}_{2 \max }\right)\end{array}$ & $\begin{array}{l}\text { - Improved aerobic capacity, reduced obesity, } \\
\text { improved glucose tolerance } \\
\text { - Normalized left ventricular mechanical efficiency } \\
\text { and mechanoenergetics } \\
\text { - Improved mitochondrial capacity and efficiency, as } \\
\text { well as reduced oxidative stress }\end{array}$ & $\begin{array}{l}\text { Hafstad et al. } \\
(47)\end{array}$ \\
\hline $\mathrm{db} / \mathrm{db}$ mice & $\begin{array}{l}300 \mathrm{~m} \text { run on a treadmill for } 5 \text { days/week at the } \\
\text { speeds of } 10-11 \mathrm{~m} / \mathrm{min} \text { for } 5 \text { weeks }\end{array}$ & $\begin{array}{l}\text { - Prevented diabetic cardiac functional deficiencies: } \\
\text { EF and FS } \\
\text { - Improvements in contraction velocity and } \\
\text { contraction maximum, OCR, and tissue ATP levels } \\
\text { - Attenuated transmembrane potential decline and } \\
\text { cytochrome c leakage }\end{array}$ & $\begin{array}{l}\text { Veeranki et al. } \\
\text { (30) }\end{array}$ \\
\hline \multicolumn{4}{|c|}{ PHYSICAL EXERCISE RELIEVES OXIDATIVE STRESS DAMAGE } \\
\hline STZ-induced diabetic Wistar rats & $\begin{array}{l}9 \text { weeks of treadmill running }(11 \mathrm{~m} / \mathrm{min}, 18 \\
\mathrm{min} / \text { day })\end{array}$ & $\begin{array}{l}\text { - Lower left atrium diameter } \\
\text { - Higher catalase and superoxide dismutase } \\
\text { activities } \\
\text { - Higher glutathione peroxidase activity }\end{array}$ & $\begin{array}{l}\text { Gimenes } \\
\text { et al. (48) }\end{array}$ \\
\hline Diabetic Goto-Kakizaki (GK) rats & $\begin{array}{l}9 \text { weeks of treadmill running ( } 60 \mathrm{~min} / \text { day and } 5 \\
\text { days/week) }\end{array}$ & $\begin{array}{l}\text { - Increased plantaris muscle cytochrome oxidase, } \\
\text { improved glycosylated hemoglobin and insulin } \\
\text { sensitivity } \\
\text { - Increased both total eNOS expression and the } \\
\text { dimer:monomer ratio in the left ventricle } \\
\text { - Increased nitric oxide (+28\%) production and } \\
\text { decreased eNOS-dependent superoxide (-12\%) } \\
\text { production } \\
\text { Decreased NADPH-dependent } \mathrm{O}_{2} \text {-activity }\end{array}$ & $\begin{array}{l}\text { Grijalva et al. } \\
(49)\end{array}$ \\
\hline Nrf2 $-/-$ mice & $\begin{array}{l}\text { Exercise on a treadmill for } 2 \text { consecutive days } \\
(60 \mathrm{~min} / \text { day; } 14 \mathrm{~m} / \mathrm{min} ; 10 \% \text { grade })\end{array}$ & $\begin{array}{l}\text { - Activated Nrf2/ARE signaling and promoted } \\
\text { antioxidant } \\
\text { - Activation of Nrf2/ARE (antioxidant response } \\
\text { element) signaling } \\
\text { - Enhancement of antioxidant defense pathways } \\
\text { - Increased trans-activation of ARE-containing } \\
\text { genes }\end{array}$ & $\begin{array}{l}\text { Muthusamy } \\
\text { et al. (50) }\end{array}$ \\
\hline
\end{tabular}


TABLE 2 | Continued

\begin{tabular}{|c|c|c|c|}
\hline Animals & Exercise intervention & Main findings & References \\
\hline STZ-induced diabetic SD rats & $\begin{array}{l}\text { Exercise on a treadmill for } 30 \text { min daily for } 4 \\
\text { weeks at a speed of } 10 \mathrm{~m} / \mathrm{min}\end{array}$ & $\begin{array}{l}\text { - Decreased the elevated tissue MDA levels } \\
\text { - Increased the reduced activities of the enzymatic } \\
\text { antioxidants SOD, GSH-Px, and CAT in cardiac } \\
\text { tissue }\end{array}$ & $\begin{array}{l}\text { Kanter et al. } \\
(51)\end{array}$ \\
\hline STZ-induced diabetic SD rats & $\begin{array}{l}\text { Exercise on a treadmill for } 60 \mathrm{~min} / \text { day on } 5 \\
\text { days for } 6 \text { weeks (10-20 m/min) }\end{array}$ & $\begin{array}{l}\text { - Higher serum level of NO and eNOS } \\
\text { - Reduced PAI-1 and VWF } \\
\text { - Reduced PKC levels }\end{array}$ & $\begin{array}{l}\text { Chengji et al. } \\
(52)\end{array}$ \\
\hline \multicolumn{4}{|c|}{ PHYSICAL EXERCISE ATTENUATES MYOCARDIAL FIBROSIS } \\
\hline $\mathrm{db} / \mathrm{db}$ mice & $\begin{array}{l}300 \mathrm{~m} \text { run on a treadmill for } 5 \text { days/week at the } \\
\text { speeds of } 10-11 \mathrm{~m} / \mathrm{min} \text { for } 5 \text { weeks }\end{array}$ & $\begin{array}{l}\text { - Normalized overall collagen accumulation at both } \\
\text { the perivascular regions and in interstitial regions of } \\
\text { heart tissue } \\
\text { - Prevented the tendency for decline in the fast } \\
\text { twitch cardiac } \mathrm{MHC} \text { isoform, } \alpha-\mathrm{MHC}\end{array}$ & $\begin{array}{l}\text { Veeranki et al. } \\
(30)\end{array}$ \\
\hline STZ-induced diabetic Wistar rats & $\begin{array}{l}\text { Swimming training for } 8 \text { weeks ( } 5 \text { days/week, } \\
90 \mathrm{~min} / \text { day, with a load of } 5 \% \text { body weight) }\end{array}$ & $\begin{array}{l}\text { - Decreased interstitial collagen and reticular fibers } \\
\text { on the extracellular matrix } \\
\text { - Attenuated glycogen accumulation }\end{array}$ & $\begin{array}{l}\text { Silva et al. } \\
(53)\end{array}$ \\
\hline $\begin{array}{l}\text { Diet-induced obesity C57BL/6 } \\
\text { mice }\end{array}$ & $\begin{array}{l}8-10 \text { weeks of treadmill running }(4 \text { min at } \\
\left.85-90 \% \text { of } \mathrm{VO}_{2 \max }\right)\end{array}$ & $\begin{array}{l}\text { - Increased the content of Mmp- } 2 \text { in obese rats, } \\
\text { increase the degradation of collagen and inhibited } \\
\text { the formation of myocardial fibrosis }\end{array}$ & $\begin{array}{l}\text { Hafstad et al. } \\
(47)\end{array}$ \\
\hline High-fat diet fed C57BL/6J mice & $\begin{array}{l}5 \text { weekly HIT ( } 10 \times 4 \text { min at } 85-90 \% \text { of } \\
\text { maximum oxygen uptake) }\end{array}$ & $\begin{array}{l}\text { - Normalized diastolic function, attenuated } \\
\text { diet-induced changes in myocardial substrate } \\
\text { utilization } \\
\text { - Inhibited cardiac reactive oxygen species content } \\
\text { and fibrosis }\end{array}$ & $\begin{array}{l}\text { Lund et al. } \\
\text { (54) }\end{array}$ \\
\hline Alloxan-induced diabetic SD rats & $\begin{array}{l}\text { Exercise on a treadmill for } 4 \text { weeks at } 80 \% \text { of } \\
\text { maximal performance }\end{array}$ & $\begin{array}{l}\text { - Inhibited cardiomyocyte hypertrophy } \\
\text { - Inhibited collagen deposition in the heart and } \\
\text { interstitial fibrosis }\end{array}$ & $\begin{array}{l}\text { Novoa et al. } \\
(55)\end{array}$ \\
\hline \multicolumn{4}{|c|}{ PHYSICAL EXERCISE INHIBITS CARDIOMYOCYTE APOPTOSIS } \\
\hline $\mathrm{db} / \mathrm{db}$ mice & $\begin{array}{l}300 \mathrm{~m} \text { run on a treadmill for } 5 \text { days/week at the } \\
\text { speeds of } 10-11 \mathrm{~m} / \mathrm{min} \text { for } 5 \text { weeks }\end{array}$ & $\begin{array}{l}\text { - Attenuated transmembrane potential decline and } \\
\text { cytochrome c leakage }\end{array}$ & $\begin{array}{l}\text { Veeranki etal. } \\
(30)\end{array}$ \\
\hline STZ-induced diabetic Wistar rats & $\begin{array}{l}\text { Exercise on a treadmill for } 60 \text { min/day, } 5 \\
\text { days/week, for } 10 \text { weeks }\end{array}$ & $\begin{array}{l}\text { - Increased cardiac survival pathway (IGF1, IGF1-R, } \\
\text { PI3K, and Akt) and the pro-survival Bcl-2 family } \\
\text { proteins (Bcl-2, Bcl-xL, and p-BAD) } \\
\text { - Reduced cardiac TUNEL-positive apoptotic cells } \\
\text { - Decreased the apoptotic key component } \\
\text { caspase-3 }\end{array}$ & $\begin{array}{l}\text { Cheng et al. } \\
(56)\end{array}$ \\
\hline STZ-induced diabetic SD rats & $\begin{array}{l}\text { Exercise on a treadmill for } 30 \text { min daily for } 4 \\
\text { weeks at a speed of } 10 \mathrm{~m} / \mathrm{min}\end{array}$ & - Reduced cardiac TUNEL-positive apoptotic cells & $\begin{array}{l}\text { Kanter et al. } \\
(51)\end{array}$ \\
\hline $\begin{array}{l}\text { High-fat high-fructose } \\
\text { diet-induced Wistar diabetic rats }\end{array}$ & $\begin{array}{l}\text { Exercise on a treadmill for } 5-\text { min at } 30-40 \% \text { of } \\
\mathrm{VO}_{2} \text { max, } 2 \text {-min intervals at } 85-90 \% \mathrm{VO}_{2} \text { max } \\
\text { with recovery cycles at } 30-40 \% \mathrm{VO}_{2} \text { max and } \\
\text { finished by } 3-\text { min cooling down by running at } \\
30-40 \% \text { of } \mathrm{VO}_{2} \text { max for } 10 \text { weeks }\end{array}$ & $\begin{array}{l}\text { - Increased the expression of Sirt1 and BCL-2 } \\
\text { - Increases LVEF\% and FS\% }\end{array}$ & $\begin{array}{l}\text { Khakdan } \\
\text { et al. (57) }\end{array}$ \\
\hline STZ-induced diabetic SD rats & $\begin{array}{l}\text { Exercise on a treadmill for } 60 \mathrm{~min} / \text { day on } 5 \\
\text { days for } 12 \text { weeks }(20 \mathrm{~m} / \mathrm{min} \text { for LIT and } 34 \\
\mathrm{m} / \mathrm{min} \text { for HIT) }\end{array}$ & $\begin{array}{l}\text { - Reduced serum cTn-I levels } \\
\text { - Reduced GRP78, CHOP, and cleaved caspase-12 } \\
\text { protein expression }\end{array}$ & $\begin{array}{l}\text { Chengjier } \\
\text { et al. (52) }\end{array}$ \\
\hline
\end{tabular}

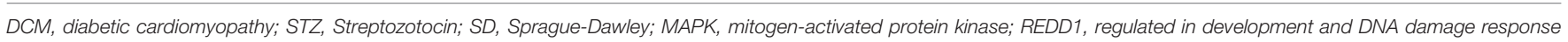

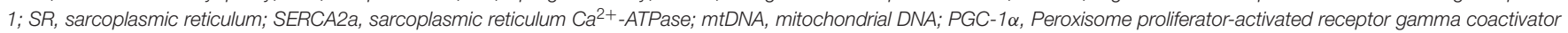

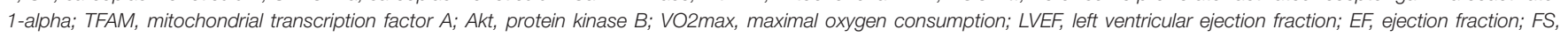

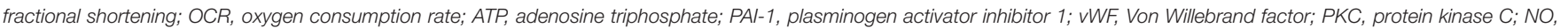

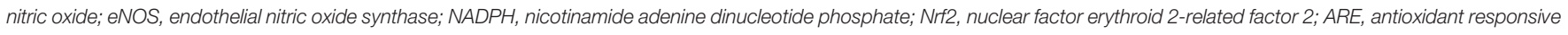

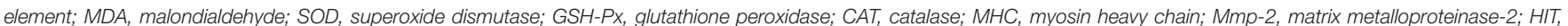

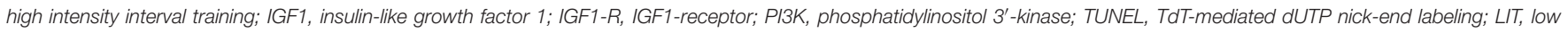
intensity exercise training; CTn-I, cardiac troponin I; Sirt1, Sirtuin 1; BCL-2, B cell leukemia/lymphoma 2; GRP78, glucose-regulated protein 78; CHOP, C/EBP homologous protein.

(BCL-2) in diabetic rats, with improved left ventricular ejection fraction (LVEF\%) and fractional shortening (FS\%) (57). A recent study suggested that exercise appeared to ameliorate DCM by inhibiting endoplasmic reticulum stress-induced apoptosis in diabetic rats, which was in an intensity-dependent manner (52).

\section{Physical Exercise Improves Microvascular Disorders}

Microvascular disease is also one of the pathological changes of DCM. Under the influence of hyperglycemia, the function and structure of microvessels will undergo pathological changes, which are characterized by vascular 


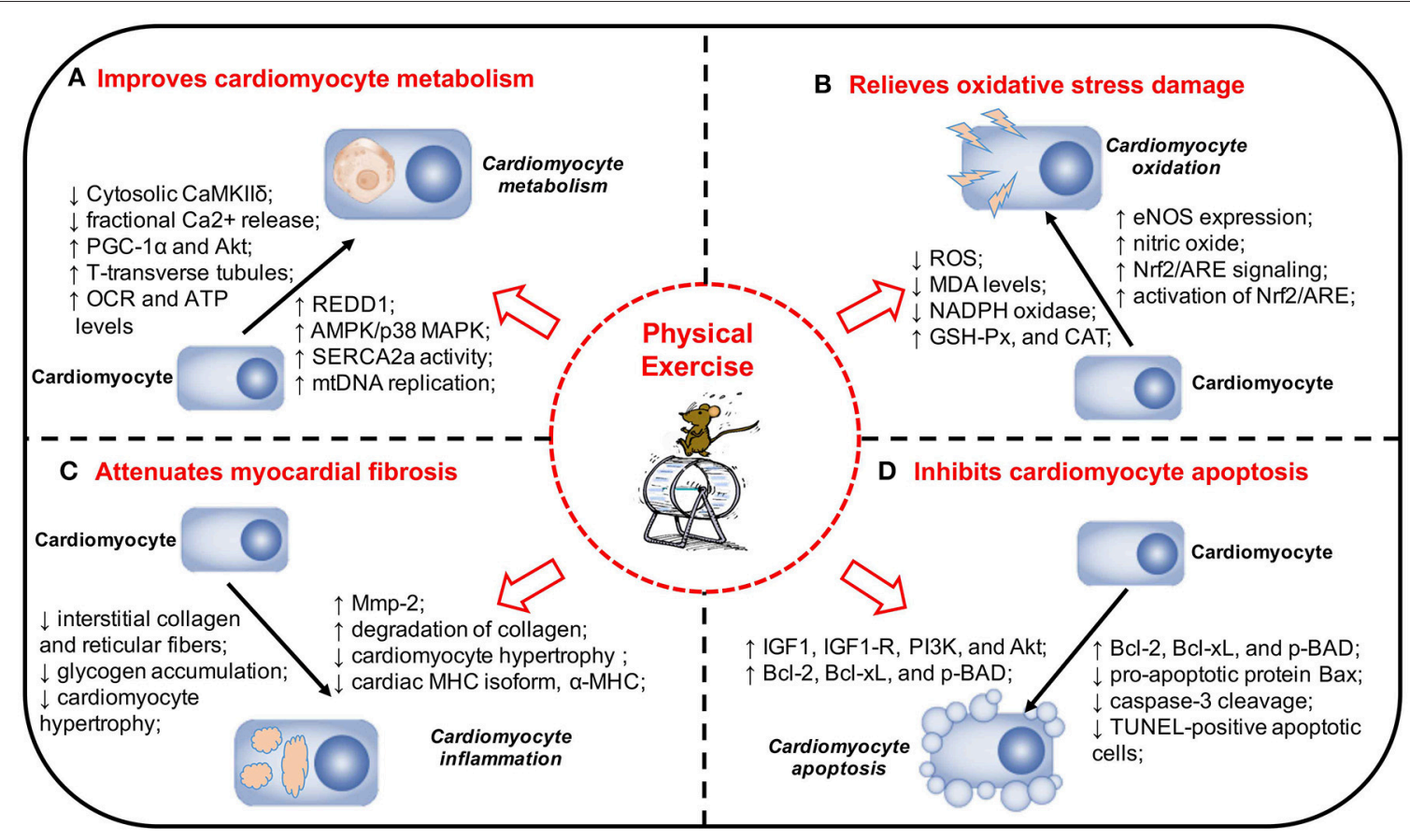

FIGURE 1 | Physical exercise and its protective effects and potential mechanisms in DCM. (A) Physical exercise Improves cardiomyocyte metabolism in DCM. (B) Physical exercise relieves oxidative stress damage in DCM. (C) Physical exercise attenuates myocardial fibrosis in DCM. (D) Physical exercise inhibits cardiomyocyte apoptosis in DCM. The pathogenesis of DCM is a multifactorial process and a range of mechanisms play a significant role in the onset and development of DCM. Physical exercise can exert a variety of protective effects on DCM, including improving cardiomyocyte metabolism, relieving oxidative stress damage, attenuating myocardial fibrosis, and inhibiting cardiomyocyte apoptosis. DCM, diabetic cardiomyopathy; MAPK, mitogen-activated protein kinase; REDD1, regulated in development and DNA damage response 1; SERCA2a, sarcoplasmic reticulum Ca2+-ATPase; mtDNA, mitochondrial DNA; PGC-1 $\alpha$, Peroxisome proliferator-activated receptor gamma coactivator 1-alpha; Akt, protein kinase B; VO2max, maximal oxygen consumption; EF, ejection fraction; FS, fractional shortening; OCR, oxygen consumption rate; ATP, adenosine triphosphate; eNOS, endothelial nitric oxide synthase; NADPH, nicotinamide adenine dinucleotide phosphate; Nrf2, nuclear factor erythroid 2-related factor 2; ARE, antioxidant responsive element; MDA, malondialdehyde; SOD, superoxide dismutase; GSH-Px, glutathione peroxidase; CAT, catalase; MHC, myosin heavy chain; Mmp-2, matrix metalloproteinase-2; IGF1, insulin-like growth factor 1; IGF1-R, IGF1-receptor; PI3K, phosphatidylinositol 3'-kinase; TUNEL, TdT-mediated dUTP Nick-End Labeling.

endothelial defects, endothelial cell dysfunction, and aggravated inflammatory response of partial vascular endothelium. It can affect the transport of substances, such as glucose and insulin into other tissues of the body, which can lead to abnormal tissue function. The mechanisms underlying the protective effects of exercise on microvessels mainly include two aspects: (1) exercise can protect vascular endothelial cells, increase the expression of nitric oxide, enhance the diastolic function of microvessels, and increase blood perfusion (66). (2) Exercise can enhance microvascular response to insulin and improve insulin signaling. Increased insulin can activate both insulin receptor substrate-1/phosphatidylinositol-3-kinase/protein kinase B (IRS-1/PI3K/AKT) and MAPK pathways, leading to equilibrium between the vasopressor substance nitric oxide and endothelin-1, ensuring normal vasomotor function (68). The pre-clinical experiments and the potential mechanisms about physical exercise and DCM is shown in Table 2 and Figure 1.

\section{CONCLUSIONS}

In summary, as a fundamental component of the human condition, physical exercise plays a critical role in human health. Exercise training is considered as a cornerstone in the management of T2DM, possessing a potency to decrease the risks of CVD in patients with diabetes. Exercise can protect the myocardium by improving myocardial cell metabolism, alleviating oxidative stress damage, improving myocardial fibrosis, inhibiting apoptosis, and ameliorating microvascular disorders, and ultimately it is proposed to have the potential impacts to protect against DCM. Exercise is an importantly nonpharmacological strategy in reducing the risk factors of diabetes and its complications. It can be considered as a promising agent for alternative therapies for the prevention and treatment of diabetes and its cardiovascular complications. However, more clinical trials and pre-clinical studies are required to promote the translation of molecular findings to therapeutics of physical exercise. 


\section{AUTHOR CONTRIBUTIONS}

JZ and JC collected data, synthesized data, and wrote the manuscript. SZ, LZ, and XHG reviewed and edited the manuscript. JQZ and XHX contributed to the design of this review.

\section{FUNDING}

This study was sponsored by National Key R\&D Program of China (2017YFC1309603), National Key Research

\section{REFERENCES}

1. International Diabetes Federation. IDF Diabetes Atlas. 8th edn. International Diabetes Federation Brussels, Belgium (2017).

2. Cai L, Kang YJ. Cell death and diabetic cardiomyopathy. Cardiovasc Toxicol. (2003) 3:219-28. doi: 10.1385/CT:3:3:219

3. Booth GL, Kapral MK, Fung K, Tu JV. Relation between age and cardiovascular disease in men and women with diabetes compared with nondiabetic people: a population-based retrospective cohort study. Lancet (2006) 368:29-36. doi: 10.1016/S0140-6736(06)68967-8

4. Sarwar N, Gao P, Seshasai SR, Gobin R, Kaptoge S, Di Angelantonio E, et al. Diabetes mellitus, fasting blood glucose concentration, and risk of vascular disease: a collaborative meta-analysis of 102 prospective studies. Lancet (2010) 375:2215-22. doi: 10.1016/S0140-6736(10)60484-9

5. Karnik AA, Fields AV, Shannon RP. Diabetic cardiomyopathy. Curr Hypertens Rep. (2007) 9:467-73. doi: 10.1007/s11906-007-0086-3

6. Murarka S, Movahed MR. Diabetic cardiomyopathy. J Card Fail. (2010) 16:971-9. doi: 10.1016/j.cardfail.2010.07.249

7. Bugger H, Abel ED. Molecular mechanisms of diabetic cardiomyopathy. Diabetologia (2014) 57:660-71. doi: 10.1007/s00125-014-3171-6

8. Jia G, Hill MA, Sowers JR. Diabetic Cardiomyopathy: an update of mechanisms contributing to this clinical entity. Circ Res. (2018) 122:624-38. doi: 10.1161/CIRCRESAHA.117.311586

9. Marwick TH, Ritchie R, Shaw JE, Kaye D. Implications of underlying mechanisms for the recognition and management of diabetic cardiomyopathy. J Am Coll Cardiol. (2018) 71:339-51. doi: 10.1016/j.jacc.2017.11.019

10. Boudina S, Abel ED. Diabetic cardiomyopathy revisited. Circulation (2007) 115:3213-23. doi: 10.1161/CIRCULATIONAHA.106.679597

11. Poirier P, Bogaty P, Garneau C, Marois L, Dumesnil JG. Diastolic dysfunction in normotensive men with well-controlled type 2 diabetes: importance of maneuvers in echocardiographic screening for preclinical diabetic cardiomyopathy. Diabetes Care (2001) 24:5-10. doi: 10.2337/diacare.24.1.5

12. Mishra PK, Ying W, Nandi SS, Bandyopadhyay GK, Patel KK, Mahata SK. Diabetic cardiomyopathy: an immunometabolic perspective. Front Endocrinol. (Lausanne). (2017) 8:72. doi: 10.3389/fendo.2017. 00072

13. Alonso N, Moliner P, Mauricio D. Pathogenesis, clinical features and treatment of diabetic cardiomyopathy. Adv Exp Med Biol. (2018) 1067:197217. doi: 10.1007/5584_2017_105

14. Anderson EJ, Kypson AP, Rodriguez E, Anderson CA, Lehr EJ, Neufer PD. Substrate-specific derangements in mitochondrial metabolism and redox balance in the atrium of the type 2 diabetic human heart. J Am Coll Cardiol. (2009) 54:1891-8. doi: 10.1016/j.jacc.2009.07.031

15. Yue Y, Meng K, Pu Y, Zhang X. Transforming growth factor beta (TGF-beta) mediates cardiac fibrosis and induces diabetic cardiomyopathy. Diabetes Res Clin Pract. (2017) 133:124-30. doi: 10.1016/j.diabres.2017. 08.018

16. Frustaci A, Kajstura J, Chimenti C, Jakoniuk I, Leri A, Maseri A, et al. Myocardial cell death in human diabetes. Circ Res. (2000) 87:1123-32. doi: 10.1161/01.RES.87.12.1123 and Development Program of China (2016YFA0101002), National Natural Science Foundation of China (No. 81170736, 81570715, 81800703), Beijing Natural Science Foundation (No. 7184252), the Fund for Fostering Young Scholars of Peking University Health Science Center (No. BMU2017PY008), China Diabetes Young Scientific Talent Research Project and BethuneMerck Diabetes Research Fund of Bethune Charitable Foundation. The funders had no role in study design, data collection and analysis, or preparation of the manuscript.

17. Pirola L, Balcerczyk A, Okabe J, El-Osta A. Epigenetic phenomena linked to diabetic complications. Nat Rev Endocrinol. (2010) 6:665-75. doi: 10.1038/nrendo.2010.188

18. GBD 2015 Risk Factors Collaborators. Global, regional, and national comparative risk assessment of 79 behavioural, environmental and occupational, and metabolic risks or clusters of risks, 1990-2015: a systematic analysis for the Global Burden of Disease Study 2015. Lancet (2016) 388:1659-724. doi: 10.1016/S0140-6736(16)31679-8

19. Nesti L, Natali A. Metformin effects on the heart and the cardiovascular system: a review of experimental and clinical data. Nutr Metab Cardiovasc Dis. (2017) 27:657-69. doi: 10.1016/j.numecd.2017.04.009

20. Eurich DT, Weir DL, Majumdar SR, Tsuyuki RT, Johnson JA, Tjosvold $\mathrm{L}$, et al. Comparative safety and effectiveness of metformin in patients with diabetes mellitus and heart failure: systematic review of observational studies involving 34,000 patients. Circ Heart Fail. (2013) 6:395-402. doi: 10.1161/CIRCHEARTFAILURE.112.000162

21. Pan G, Deshpande M, Pang H, Palaniyandi SS. Precision medicine approach: empagliflozin for diabetic cardiomyopathy in mice with aldehyde dehydrogenase (ALDH) 2*2 mutation, a specific genetic mutation in millions of East Asians. Eur J Pharmacol. (2018) 839:76-81. doi: 10.1016/j.ejphar.2018.09.021

22. Pedersen BK, Febbraio MA. Muscles, exercise and obesity: skeletal muscle as a secretory organ. Nat Rev Endocrinol. (2012) 8:457-65. doi: 10.1038/nrendo.2012.49

23. Orlando G, Balducci S, Bazzucchi I, Pugliese G, Sacchetti M. Neuromuscular dysfunction in type 2 diabetes: underlying mechanisms and effect of resistance training. Diabetes Metab Res Rev. (2016) 32:40-50. doi: 10.1002/dmrr.2658

24. Cheema BS, Chan D, Fahey P, Atlantis E. Effect of progressive resistance training on measures of skeletal muscle hypertrophy, muscular strength and health-related quality of life in patients with chronic kidney disease: a systematic review and meta-analysis. Sports Med. (2014) 44:1125-38. doi: 10.1007/s40279-014-0176-8

25. Knobf MT, Winters-Stone K. Exercise and cancer. Annu Rev Nurs Res. (2013) 31:327-65. doi: 10.1891/0739-6686.31.327

26. Mann N, Rosenzweig A. Can exercise teach us how to treat heart disease? Circulation (2012) 126:2625-35. doi: 10.1161/CIRCULATIONAHA.111.060376

27. Fletcher GF, Ades PA, Kligfield P, Arena R, Balady GJ, Bittner VA, et al. Exercise standards for testing and training: a scientific statement from the American Heart Association. Circulation (2013) 128:873-934. doi: 10.1161/CIR.0b013e31829b5b44

28. Rowe GC, Safdar A, Arany Z. Running forward: new frontiers in endurance exercise biology. Circulation (2014) 129:798-810. doi: 10.1161/CIRCULATIONAHA.113.001590

29. De Lemos ET, Oliveira J, Pinheiro JP, Reis F. Regular physical exercise as a strategy to improve antioxidant and anti-inflammatory status: benefits in type 2 diabetes mellitus. Oxid Med Cell Longev. (2012) 2012:741545. doi: $10.1155 / 2012 / 741545$

30. Veeranki S, Givvimani S, Kundu S, Metreveli N, Pushpakumar S, Tyagi SC. Moderate intensity exercise prevents diabetic cardiomyopathy associated contractile dysfunction through restoration of mitochondrial function and 
connexin 43 levels in db/db mice. J Mol Cell Cardiol. (2016) 92:163-73. doi: 10.1016/j.yjmcc.2016.01.023

31. Jakicic JM, Jaramillo SA, Balasubramanyam A, Bancroft B, Curtis JM, Mathews A, et al. Effect of a lifestyle intervention on change in cardiorespiratory fitness in adults with type 2 diabetes: results from the Look AHEAD Study. Int J Obes (Lond). (2009) 33:305-16. doi: 10.1038/ijo.2008.280

32. Tanasescu M, Leitzmann MF, Rimm EB, Hu FB. Physical activity in relation to cardiovascular disease and total mortality among men with type 2 diabetes. Circulation (2003) 107:2435-9. doi: 10.1161/01.CIR.0000066906.11109.1F

33. Cardoso CR, Maia MD, De Oliveira FP, Leite NC, Salles GF. High fitness is associated with a better cardiovascular risk profile in patients with type 2 diabetes mellitus. Hypertens Res. (2011) 34:856-61. doi: 10.1038/hr.2011.50

34. Hu G, Jousilahti P, Barengo NC, Qiao Q, Lakka TA, Tuomilehto J. Physical activity, cardiovascular risk factors, and mortality among Finnish adults with diabetes. Diabetes Care (2005) 28:799-805. doi: 10.2337/diacare.28.4.799

35. Karjalainen JJ, Kiviniemi AM, Hautala AJ, Piira OP, Lepojarvi ES, Perkiomaki JS, et al. Effects of physical activity and exercise training on cardiovascular risk in coronary artery disease patients with and without type 2 diabetes. Diabetes Care (2015) 38:706-15. doi: 10.2337/dc14-2216

36. Hansen D, Dendale P, Van Loon LJ, Meeusen R. The impact of training modalities on the clinical benefits of exercise intervention in patients with cardiovascular disease risk or type 2 diabetes mellitus. Sports Med. (2010) 40:921-40. doi: 10.2165/11535930-000000000-00000

37. Lavie CJ, Johannsen N, Swift D, Senechal M, Earnest C, Church T, et al. Exercise is Medicine - the importance of physical activity, exercise training, cardiorespiratory fitness and obesity in the prevention and treatment of type 2 Diabetes. Eur Endocrinol. (2014) 10:18-22. doi: 10.17925/EE.2014.10.01.18

38. Anand V, Garg S, Garg J, Bano S, Pritzker M. Impact of exercise training on cardiac function among patients with type 2 diabetes: a systematic review and meta-analysis. J Cardiopulm Rehabil Prev. (2018) 38:358-65. doi: 10.1097/HCR.0000000000000353

39. American Diabetes Association. 4. Lifestyle Management: Standards of Medical Care in Diabetes-2018. Diabetes Care (2018) 41:S38-50. doi: $10.2337 / \mathrm{dc} 18$-S004

40. Pieri BL, Souza DR, Luciano TF, Marques SO, Pauli JR, Silva AS, et al. Effects of physical exercise on the P38MAPK/REDD1/14-3-3 pathways in the myocardium of diet-induced obesity rats. Horm Metab Res. (2014) 46:621-7. doi: 10.1055/s-0034-1371824

41. Epp RA, Susser SE, Morissette MP, Kehler DS, Jassal DS, Duhamel TA. Exercise training prevents the development of cardiac dysfunction in the lowdose streptozotocin diabetic rats fed a high-fat diet. Can J Physiol Pharmacol. (2013) 91:80-9. doi: 10.1139/cjpp-2012-0294

42. Stolen TO, Hoydal MA, Kemi OJ, Catalucci D, Ceci M, Aasum E, et al. Interval training normalizes cardiomyocyte function, diastolic $\mathrm{Ca}^{2+}$ control, and SR $\mathrm{Ca}^{2+}$ release synchronicity in a mouse model of diabetic cardiomyopathy. Circ Res. (2009) 105:527-36. doi: 10.1161/CIRCRESAHA.109.199810

43. Searls YM, Smirnova IV, Fegley BR, Stehno-Bittel L. Exercise attenuates diabetes-induced ultrastructural changes in rat cardiac tissue. Med Sci Sports Exerc. (2004) 36:1863-70. doi: 10.1249/01.MSS.0000145461.38224.EC

44. Wang H, Bei Y, Lu Y, Sun W, Liu Q, Wang Y, et al. Exercise prevents cardiac injury and improves mitochondrial biogenesis in advanced diabetic cardiomyopathy with PGC-1 $\alpha$ and Akt activation. Cell Physiol Biochem. (2015) 35:2159-68. doi: 10.1159/000374021

45. Ko TH, Marquez JC, Kim HK, Jeong SH, Lee S, Youm JB, et al. Resistance exercise improves cardiac function and mitochondrial efficiency in diabetic rat hearts. Pflugers Arch. (2018) 470:263-75. doi: 10.1007/s00424-017-2076-x

46. Hafstad AD, Boardman NT, Lund J, Hagve M, Khalid AM, Wisloff U, et al. High intensity interval training alters substrate utilization and reduces oxygen consumption in the heart. J Appl Physiol. (2011) 111:1235-41. doi: 10.1152 /japplphysiol.00594.2011

47. Hafstad AD, Lund J, Hadler-Olsen E, HöPer AC, Larsen TS, Aasum E High- and moderate-intensity training normalizes ventricular function and mechanoenergetics in mice with diet-induced obesity. Diabetes (2013) 62:2287-94. doi: $10.2337 / \mathrm{db} 12-1580$

48. Gimenes C, Gimenes R, Rosa CM, Xavier NP, Campos DH, Fernandes AA, et al. Low intensity physical exercise attenuates cardiac remodeling and myocardial oxidative stress and dysfunction in diabetic rats. J Diabetes Res. (2015) 2015:457848. doi: 10.1155/2015/457848
49. Grijalva J, Hicks S, Zhao X, Medikayala S, Kaminski PM, Wolin MS, et al. Exercise training enhanced myocardial endothelial nitric oxide synthase (eNOS) function in diabetic Goto-Kakizaki (GK) rats. Cardiovasc Diabetol. (2008) 7:34. doi: 10.1186/1475-2840-7-34

50. Muthusamy VR, Kannan S, Sadhaasivam K, Gounder SS, Davidson CJ, Boeheme C, et al. Acute exercise stress activates Nrf2/ARE signaling and promotes antioxidant mechanisms in the myocardium. Free Radic Biol Med. (2012) 52:366-76. doi: 10.1016/j.freeradbiomed.2011. 10.440

51. Kanter M, Aksu F, Takir M, Kostek O, Kanter B, Oymagil A. Effects of low intensity exercise against apoptosis and oxidative stress in streptozotocininduced diabetic rat heart. Exp Clin Endocrinol Diabetes (2017) 125:583-91. doi: $10.1055 / \mathrm{s}-0035-1569332$

52. Chengji W, Xianjin F. Exercise protects against diabetic cardiomyopathy by the inhibition of the endoplasmic reticulum stress pathway in rats. J Cell Physiol. (2019) 234:1682-88. doi: 10.1002/jcp.27038

53. Silva E, Natali AJ, Silva MF, Gomes GJ, Cunha DN, Ramos RM, et al. Ventricular remodeling in growing rats with experimental diabetes: the impact of swimming training. Pathol Res Pract. (2013) 209:618-26. doi: 10.1016/j.prp.2013.06.009

54. Lund J, Hafstad AD, Boardman NT, Rossvoll L, Rolim NP, Ahmed MS, et al. Exercise training promotes cardioprotection through oxygen-sparing action in high fat-fed mice. Am J Physiol Heart Circ Physiol. (2015) 308:H823-829. doi: 10.1152/ajpheart.00734.2014

55. Novoa U, Arauna D, Moran M, Nunez M, Zagmutt S, Saldivia S, et al. High-intensity exercise reduces cardiac fibrosis and hypertrophy but does not restore the nitroso-redox imbalance in diabetic cardiomyopathy. Oxid Med Cell Longev. (2017) 2017:7921363. doi: 10.1155/2017/79 21363

56. Cheng SM, Ho TJ, Yang AL, Chen IJ, Kao CL, Wu FN, et al. Exercise training enhances cardiac IGFI-R/PI3K/Akt and Bcl-2 family associated prosurvival pathways in streptozotocin-induced diabetic rats. Int J Cardiol. (2013) 167:478-85. doi: 10.1016/j.ijcard.2012.01.031

57. Khakdan S, Delfan M, Heydarpour Meymeh M, Kazerouni F, Ghaedi H, Shanaki M, et al. High-intensity interval training (HIIT) effectively enhances heart function via miR-195 dependent cardiomyopathy reduction in high-fat high-fructose diet-induced diabetic rats. Arch Physiol Biochem. (2018) 15:1-8. doi: 10.1080/13813455.2018.1511599

58. Garvey WT, Hardin D, Juhaszova M, Dominguez JH. Effects of diabetes on myocardial glucose transport system in rats: implications for diabetic cardiomyopathy. Am J Physiol. (1993) 264:H837-44. doi: 10.1152/ajpheart.1993.264.3.H837

59. Nakai N, Miyazaki Y, Sato Y, Oshida Y, Nagasaki M, Tanaka M, et al. Exercise training increases the activity of pyruvate dehydrogenase complex in skeletal muscle of diabetic rats. Endocr J. (2002) 49:547-54. doi: $10.1507 /$ endocr. 49.547

60. Heled Y, Shapiro Y, Shani Y, Moran DS, Langzam L, Braiman L, et al. Physical exercise prevents the development of type 2 diabetes mellitus in Psammomys obesus. Am J Physiol Endocrinol Metab. (2002) 282:E370-5. doi: 10.1152/ajpendo.00296.2001

61. Pold R, Jensen LS, Jessen N, Buhl ES, Schmitz O, Flyvbjerg A, et al. Long-term AICAR administration and exercise prevents diabetes in ZDF rats. Diabetes (2005) 54:928-34. doi: 10.2337/diabetes.54.4.928

62. Waller AP, Kalyanasundaram A, Hayes S, Periasamy M, Lacombe VA. Sarcoplasmic reticulum $\mathrm{Ca}^{2+}$ ATPase pump is a major regulator of glucose transport in the healthy and diabetic heart. Biochim Biophys Acta (2015) 1852:873-81. doi: 10.1016/j.bbadis.2015.01.009

63. Croston TL, Thapa D, Holden AA, Tveter KJ, Lewis SE, Shepherd DL, et al. Functional deficiencies of Subsarcolemmal mitochondria in the type 2 diabetic human heart. Am J Physiol Heart Circ Physiol. (2014) 307:H54-65. doi: 10.1152/ajpheart.00845.2013

64. Burgoyne JR, Mongue-Din H, Eaton P, Shah AM. Redox signaling in cardiac physiology and pathology. Circ Res. (2012) 111:1091-106. doi: 10.1161/CIRCRESAHA.111.255216

65. Narasimhan M, Rajasekaran NS. Exercise, Nrf2 and antioxidant signaling in cardiac aging. Front Physiol. (2016) 7:241. doi: 10.3389/fphys.2016.00241

66. Cohen ND, Dunstan DW, Robinson C, Vulikh E, Zimmet PZ, Shaw JE. Improved endothelial function following a 14-month 
resistance exercise training program in adults with type 2 diabetes. Diabetes Res Clin Pract. (2008) 79:405-11. doi: 10.1016/j.diabres.2007. 09.020

67. Zhou YY, Li Y, Jiang WQ, Zhou LF. MAPK/JNK signalling: a potential autophagy regulation pathway. Biosci Rep. (2015) 35:e00199. doi: 10.1042/BSR20140141

68. Kim JA, Montagnani M, Koh KK, Quon MJ. Reciprocal relationships between insulin resistance and endothelial dysfunction: molecular and pathophysiological mechanisms. Circulation (2006) 113:1888-904. doi: 10.1161/CIRCULATIONAHA.105.
Conflict of Interest Statement: The authors declare that the research was conducted in the absence of any commercial or financial relationships that could be construed as a potential conflict of interest.

Copyright $\odot 2018$ Zheng, Cheng, Zheng, Zhang, Guo, Zhang and Xiao. This is an open-access article distributed under the terms of the Creative Commons Attribution License (CC BY). The use, distribution or reproduction in other forums is permitted, provided the original author(s) and the copyright owner(s) are credited and that the original publication in this journal is cited, in accordance with accepted academic practice. No use, distribution or reproduction is permitted which does not comply with these terms. 